\title{
Molecular evolution of 'eye genes' in blind beetles from the calcrete archipelago of Western Australia: evidence for neutral evolution of phototransduction genes
}

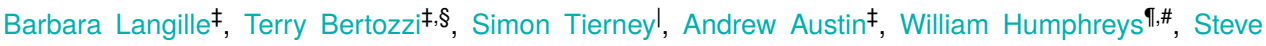 \\ Cooper $¥, \S$ \\ ‡ The University of Adelaide, Adelaide, Australia \\ $\S$ South Australian Museum, Adelaide, Australia \\ I Western Sydney University, Sydney, Australia \\ I Western Australian Museum, Welshpool WA 6106, Australia \\ \# Western Australian Museum, Perth, Australia
}

\section{Corresponding author: Barbara Langille (barbara.langille@adelaide.edu.au)}

\section{Received: 02 Oct 2018 | Published: 02 Oct 2018}

Citation: Langille B, Bertozzi T, Tierney S, Austin A, Humphreys W, Cooper S (2018) Molecular evolution of 'eye genes' in blind beetles from the calcrete archipelago of Western Australia: evidence for neutral evolution of phototransduction genes. ARPHA Conference Abstracts 1: e30237. https://doi.org/10.3897/aca.1.e30237

\section{Abstract}

Neutral evolution theory predicts that genes specific to the development/function of eyes in subterranean animals will evolve under relaxed selection, ultimately becoming pseudogenes. Independently evolved (3-8 million years ago) subterranean beetle (Dytiscidae) species of Western Australia have converged on eye loss, providing a powerful system to explore changes to the genome with respect to troglomorphic characters. Using next generation sequence data, we investigated the molecular evolution of 'eye genes' of subterranean beetle species to test if they are evolving neutrally. We used transcriptome data from five beetle species (three subterranean and two surface) to design baits for hybrid enrichment of 60 pigmentation and phototransduction genes from 31 subterranean and surface species. The current talk focuses on the results from the study of 8 photoreceptor genes that showed evidence for a lack of transcription or possible pseudogenisation in stygobitic species when compared to surface species. The mutations 
found in these genes included multiple insertions or deletions, resulting in frameshifts which led to the introduction of stop codons. Our study provides evidence for the parallel loss of key phototransduction genes, lending support to the neutral theory of regressive evolution.

\section{Keywords}

Dytiscidae, regressive evolution, eye loss, subterranean beetles, opsin, arrestin, phototransduction, neutral evolution theory, pseudogene

\section{Presenting author}

Barbara Langille

\section{Presented at}

$24^{\text {th }}$ International Conference on Subterranean Biology

\section{Grant title}

ARC Discovery project DP120102132

\section{Hosting institution}

The University of Aveiro 